\title{
"WATER IS LIFE, LIFE IS WATER": THE (UN)SUSTAINABLE USE AND MANAGEMENT OF WATER IN THE TWENTY-FIRST CENTURY
}

\author{
GAURI SHANKAR GUPTA - ANNAMÁRIA ORBÁN ${ }^{l}$
}

\begin{abstract}
Few things have a greater impact on our lives than water. Water is a paradox: it is a seemingly abundant and renewable resource, while only a tiny amount of it is accessible and drinkable. Moreover, global water resources are unevenly distributed and many of them have been contaminated. Millions of people struggle with water scarcity, in many cases leading to water-related international conflict. Water is an international public good and is associated with common pool resources (CPR) and collective action problems whose solution calls for international cooperation and action. Well-developed ancient civilizations have disappeared because of human environmental degradation, bad resource management and related socio-political problems. We should learn the lessons from our ancestors, and therefore wisely manage our natural resources. Socio-cultural instruments such as sustainable water governance, policy and communication can be as important as high-tech engineering for human survival from a historical perspective. Our paper is a theoretical overview and analysis of the most challenging water-related issues and problems, providing theoretical as well as practical, policy-oriented solutions.
\end{abstract}

KEYWORDS: water, public goods, sustainable water use and governance, international cooperation

\footnotetext{
1 Gauri Shankar Gupta is former Ambassador/ High Commissioner of India, author and motivational speaker, Jaipur, India, e-mail: gaurishankargupta@yahoo.co.in. Annamária Orbán, PhD, associate professor, Budapest University of Technology and Economics (BME), Department of Sociology and Communication, Centre for Socio-Spatial Development Studies, Budapest, Hungary, corresponding author, e-mail: aOrbán@eik.bme.hu.
} 


\section{INTRODUCTION}

"Water is life, life is water", the old African idiom says, which is undoubtedly true in many senses. The existence of life is inconceivable without water. Water is an essential pre-requisite for existence and sustenance of life in any form. Living species on Earth, both plants and animals, cannot survive without water. We, humans, need and use water in many forms: to maintain basic health and sanitation, to feed ourselves through agriculture (the primary use of water $-70 \%$ ) not to speak about its different uses in industry $(20 \%)^{2}$. Thus, few substances have greater impact on our lives and the life of the planet than water. Water is a paradox and paradoxical. It is a seemingly abundant and renewable resource on our "Blue Planet" (seen as blue from space by astronauts). However, only a tiny amount of global water resources are accessible and drinkable (less than $1 \%$ ), and these are unfortunately unevenly distributed globally. In many regions and countries of the world, especially in the Middle East and North Africa (MENA) - meaning roughly 400 million people - individuals struggle with water scarcity either directly or indirectly, leading to regional water-related conflicts, although not to inter-state or civil wars, unlike in the case of oil - so far (Lowi 2008).

If we look at human history, all major ancient civilizations have developed next to river banks. Egyptian - the Nile; Mesopotamia - the Tigris and Euphrates; Indian - the Indus, Ganges and Brahmaputra; Chinese - the Yangtze and Yellow River. Rivers and lakes continue to be the lifeline of the human race despite the record-breaking technological achievements of recent times. All the major cities of the world are located either on river banks, on the shores of fresh water lakes, or in coastal areas. Thus, life and water are closely linked. Over twothirds of the land on Earth is covered with water. Scientists who search for the existence of life on other planets look for traces of water, for no life is possible without it. Apart from the direct consumption of water for drinking, cleaning and cooking, water is also a requirement for food production and navigation. Hence, the water cycle is intrinsically linked to the biological life cycle. It is precisely for this reason that the power of water has been acknowledged in different civilizations and cultures since ancient times. In Hindu and Greek cultures, water is associated with powerful gods.

With the extreme and rapid changes in our climate, along with their environmental consequences, especially severe droughts and an increasing number of water-scarce areas in the world, we cannot exclude water as a source of future international conflict. However, experts say that despite this gloomy

2 See more detail on Page 85.

CORVINUS JOURNAL OF SOCIOLOGY AND SOCIAL POLICY VOL. 9 (2018) 1 
scenario interstate war is unlikely based on historical facts, as no nations have gone to war specifically over water resources for thousands of years. Moreover, instances of cooperation between riparian nations outnumbered conflicts by more than 2-to-1 between 1945 and 1999 (Kameri-Mbote 2007: 3). We hope that this trend will not change in the future.

On the other hand, there is historical and archeological evidence that many well-developed ancient civilizations have disappeared, vanished or destroyed themselves because of human environmental degradation, bad resource management and related problems such as deforestation, overgrazing, erosion, water overuse and scarcity. Diamond (1994) lists many examples of the ecological collapse of ancient civilizations, from Easter Island through the North American Chaco Canyon to the Middle East. Based on archeological evidence and other contemporary accounts, Diamond has a plausible explanation for the collapse of these human societies: overuse and ruination of natural resources. Another study says that water reservoirs provide relief during short periods of drought, but can make a society even more vulnerable to major catastrophes if a population keeps growing without changing its habits. New models suggest that this phenomenon could have caused the demise of the Maya civilization (Kuil et al. 2016). It is very important that we should learn lessons from our ancestors and draw important conclusions for our own future. Technology and perfect engineering are not enough: we need to be careful with our natural resources and manage them wisely, but also pay attention to socio-cultural factors which may be more important for survival from a historic perspective. As Diamond says, it is "beyond understanding to see modern societies repeating the past's suicidal ecological mismanagement, with much more powerful tools of destruction in the hands of far more people" (Diamond 1994: 59).

\section{WATER RESOURCES AND PUBLIC GOODS}

The natural resources - including water and environmental sustainability (for instance, in the form of the provision of safe drinking water) - which are mentioned in the UN Millennium Development Goals (MDGs) and are targeted in the recent UN Sustainable Development Goals (SDGs) ${ }^{3}$ - are public goods. Public goods - according to the strictly economic "textbook" definition - are goods (or services) which i) once provided it is not desirable or feasible to

3 See Goal 6 of the UN SDGs, accessed at http://www.un.org/sustainabledevelopment/sustainabledevelopment-goals/ 15 December 2017. 
exclude anybody from their consumption/benefits (non-excludability), and ii) the appearance of new consumers does not reduce the consumption of others of such goods/services, either quantitatively or qualitatively (non-rivalry). The concept of public goods does not only apply to the consumption of the good, but also to its production. On the other hand, the concept of public goods is a parabola: a symbolic formulation of collective action (Olson 1971) and common pool resource (CPR) problems (see for example, Ostrom 1990). CPR problems involve the so-called "tragedy of the commons" (Hardin 1968) which may occur from "overuse" of the same meadow or spring located in the catchment basin of a region, to overexploitation of Earth's drinkable water sources more generally.

In other words, "social traps" (Hankiss 1979) are closely connected to the cooperation of large latent groups and the problem of collective action (Olson 1971). The impact of the individual may become lost in large-sized human groups - be they a city or the whole global community - because the activity or potential contribution of the former to the community is "marginal" or unnoticeable, appearing worthless. Strongly connected to this situation, the phenomenon of "free-riding" means that, according to (narrowly) rational - i.e. short-sighted and self-interested - individuals, it is not worth contributing to the production of public goods because others will do this. This approach engenders the development of a vicious circle: if others provide a public good, nobody can be excluded from its consumption, and there is a big temptation to free-ride. Nonetheless, according to game theory, free-riding is a dominant strategy: since any individual player will be better off by free-riding regardless of what others do, they will not act to support the creation of the public good. Thus the social trap "closes", meaning that the interests of the individual and the community appear to contrast with each other, because in the case in which everybody takes into account only their own, short-term self-interests, and in addition, the contribution of individuals is negligible, production of a public good is doubtful (Orbán 2005).

A great number of examples may be enumerated, but let us return to our starting point, to environmental problems; more specifically, to water pollution and overuse, such problems that might be interpreted using the concept of the public good-collective action problem. We have already mentioned several examples from earlier centuries, ranging from overuse through exploitation of natural resources to modern-day contamination of waters (later discussed) in relation to the activity of individual farmers, multinational corporations or larger communities, such as ever-growing mega cities. If everybody only sees abundance and diminishes their own role in terms of water "consumption" or pollution, sooner or later the whole of mankind will end up trapped, and there will be nothing left to be used up. 
Fortunately, there are several ways of escaping this global social trap. Elinor Ostrom (1990) mentions empirical cases of cooperative norms arising as a result of repeated community interaction and instances in which communities have successfully dealt with CPR problems. Another solution may be - most feasibly, in the short-term - an external compelling force which encourages members of the community in the broadest sense to really contribute to the production of the public good, or to recognize the severity of consequences that their short-term rational thinking entails. This external compelling force in practice may appear as an international agreement or - in the best case - a law, which should be observed by everybody (Orbán 2005). Thus we arrive at international negotiations and mutual agreements which may lead us out of such global social traps as environmental/water pollution and overuse of common pool resources (CPR). Moreover, they may help with the formation of global partnerships for mutual understanding and identifying cooperative solutions, like the previously mentioned UN MDG, the 2015 UN SDG, or various international forums like the Budapest Water Summit 2016 (see later).

Nonetheless, we should emphasize that international environmental - or sustainable water governance - agreements themselves are a necessary but not sufficient condition for problem solving. To promote observation and enforcement of rules, various positive (for example, material and intangible rewards) or negative incentives (sanctions; Olson 1971) and other controlling mechanisms and institutions (see Ostrom 1990) are needed. In an ideal case, such norms or ethics which do not require any other punitive instruments of enforcement are enough by themselves, by virtue of the word that is given, or "gentlemen's agreements" (Orbán 2005).

When we think of Earth's water resources, we think of oceans, seas, lakes, and rivers. Water resources like these are called surface waters. Not all of Earth's water lies on its surface, however. A great deal of water is held in underground rock structures known as aquifers, which we cannot see and seldom think about. Water stored underground in aquifers is known as groundwater. Groundwater represents about 30 percent of total fresh water (Pennington - Cech 2010). Aquifers feed our rivers and supply much of our drinking water. In many places water from aquifers is also used for agriculture. Thus water is found everywhere on Earth and is the only substance that can naturally be found in liquid, solid and gaseous form. Earth contains approximately 1.40 billion cubic kilometers of water, with 96.5 percent of this in oceans. Fresh water amounts to approximately 36 million cubic kilometers, constituting only 2.6 percent of total. Of this, only 11 million cubic kilometers or 0.77 percent counts as part of the water cycle while the rest is locked in glaciers, polar ice caps and permanent snow (Barlow - Clarke 2002: 5). According to another estimate, approximately 1.7 percent of 
all water is stored in glaciers, permanent snow and polar ice caps while another 1.7 percent exists as ground water and in rivers, lakes, wetlands and soil. The remaining 0.1 percent is contained in Earth's atmosphere (Pennington - Cech 2010:2). Thus, fresh water supplies constitute a very small proportion of total water resources. Rain, which forms a crucial part of the hydrological cycle, keeps continuously recharging both surface and the ground water sources. Thus, the natural process is a self-sustaining process that keeps water pollution free.

Globally fresh water is abundant enough to sustain life. However, it is not evenly distributed across the continents, and its availability varies from season to season and year to year. For example, in much of India 90 percent of rainfall occurs during the monsoon season between June and September. Similarly, the Amazon River Basin in South America receives approximately 15 percent of world's surface water runoff, but supports only 0.4 percent of Earth's population. Asia, on the other hand, contains 69 percent of the world's population but receives only 36 percent of Earth's surface water runoff (Pennington - Cech 2010:2).

A country is said to be water stressed when there is less than 1000 cubic meters of water per person per year. Below this level the health and economic well-being of a nation is compromised (Shiva 2000; Chellaney 2011: 9). Some of the world's fastest growing economies - China, India, South Korea and Vietnam - are in a near water-stressed condition (Chellaney, 2011: 9). According to the International Water Management Institute, one in three people globally endure some sort of water scarcity, one quarter of the world's population live in areas where water is physically scarce, and over one billion people live where water is economically scarce (Escobar-Schafer, 2010: 3). Water is likely to be the most pressing environmental concern this century. As the global population continues to grow exponentially and as environmental change shifts the location of the sources, timing, quality and quantity of water, the ability of nations and states to peacefully manage conflicts over water resources will be increasingly at the heart of international relations and political stability of many countries (Priscoli - Wolf, 2009: 1).

We know that the battles of yesteryear were fought over land for building empires and colonies. Those of today are being fought over energy resources and the theft of technology. However, the battles of tomorrow are likely to be fought over water, which is gradually emerging as the single most important natural resource due to growing demand across the globe. The very survival of human and other species could be threatened if the current level of water stress and overuse continues. Industrial and private water demands have grown to exceed natural supplies in many parts of the world. Without dramatic changes in water management, this local scarcity will soon expand to regional or global proportions, transforming 
into "water shock" and then to "water famine," displacing millions or perhaps billions of people. In 1998, 28 countries experienced water stress or scarcity. This number is expected to rise to 56 by 2025 (Shiva 2000:1). The specter of water wars is also being heightened by climate change and environmental degradation in the form of shrinking forests and over-damming of rivers which fosters a cycle of chronic flooding and droughts. The Himalayan snowmelt that feeds Asia's greatest rivers could be dangerously accelerated by global warming, leading to serious river depletion. As water stress intensifies and global warming accelerates, local, national and inter-state disputes over water are likely to become endemic in Asia (Chellaney, 2011: 11).

\section{WATER USERS, WATER POLLUTION}

According to a report by the World Commission on Water, agriculture currently accounts for roughly 70 percent of water utilization, industries 20 percent, and domestic or municipal consumption 10 percent (World Water Vision 2000: 7). Therefore, all the sources of water stated earlier are under threat for multiple reasons. Firstly, the world's population is exploding, putting unprecedented demand on water resources. Global population has increased from 1.6 billion in 1900 to 7.4 billion in 2016 and is expected to reach 11.2 billion by 2100 (Population Reference Bureau, 2016: 1). Increasing population has put extraordinary pressure on rivers and lakes all over the world, but in particularly in China, South Asia and the Middle East. Second, an increasing number of people are moving to cities. This has resulted in large-scale migration to cities with high density urban areas. Cities are growing because basic infrastructure and opportunities are comparatively poorer in rural areas. Job opportunities, the cultural landscape, educational facilities, health care and social services are generally much better in urban areas. The total percentage of people living in urban areas increased from 37 percent in 1970 to 45 percent in 1994 and is projected to reach 60 percent by 2025 (UN World Urbanization Prospects 2014: 1). Continuing large-scale migration is putting unprecedented strain on water supplies in cities, resulting in the breakdown of sanitation services. Third, per capita water consumption is multiplying, roughly doubling every twenty years. From 1940 to 1990, withdrawals of water for human consumption increased by more than a factor of four, reflecting the long-term trend to increasing withdrawals per capita. Per capita availability of fresh water on a global basis fell from $17,000 \mathrm{~m}^{3}$ in 1950 to $7,300 \mathrm{~m}^{3}$ in 1995 (National Research Council, 1999:90). The increasing industrial use of water, the growing needs 
of agriculture, the flushing of toilets by a growing number of urban inhabitants and leakages in municipal infrastructure are taking a severe toll on fresh water supplies. As technology has developed, communities have gained easier access to water. Instead of people 'following the water' by settling near rivers, lakes and springs, communities have moved the water to their settlement centers by constructing reservoirs and pipe lines. Technology has also allowed us to lift water to high-rise buildings, thousands of meters above surface level. Most of the world's large dams have been built in the post-World War II period to redirect rivers and channel water for irrigation and municipal consumption (Chellaney 2013). Thus, human efforts to control and redirect water and its easy availability due to mechanized systems for pumping water have resulted in a multifold increase in use, as well as the misuse of water.

Growing demand for food due to the increasing population and higher per capita consumption has led to a substantial increase in the use of fresh water for agriculture. Powered by technological innovation, new irrigation techniques based on the diversion of rivers through dams and reservoirs, the construction of canals, pump irrigation, drip irrigation and so on have come into being. As a result, total irrigated land area has gone up many fold. According to the Food and Agriculture Organization in 2012, 324 million hectares of land were equipped for irrigation, compared to an estimated 40 million hectares in 1900 (FAO 2016). Industrial farming has become another big drain on fresh water resources across the globe. The use of water for agriculture has also gone up substantially due to the introduction of high yielding varieties of food grains and the increasing use of chemical fertilizers, which are water intensive.

Production of 'bio-fuel' is very water intensive. As much as 2500 liters of water are needed to grow enough corn to be refined into a single liter of ethanol. Therefore, the new fashion for bio-fuel in the name of green energy represents a big drain on the fresh water resources of the planet. This trend is also diverting land use from traditional food crops to bio-fuel production, adversely affecting the output of traditional food crops, making them more expensive (Chellaney 2013: 64-69). The supply of electric power in many areas of India, China and Africa has enabled the mechanized withdrawal of groundwater by large sections of population, contributing to higher water consumption both for agriculture and domestic use. Similarly, the industrial production of meat and poultry is highly water intensive. The actual water requirements of different food products may vary considerably depending on soil condition, climate and irrigation techniques. Thus, the growing consumption of meat and poultry products is becoming a drain on fresh water globally. Since some of these industrial farming practices are even subsidized, they are in fact promoting the over-use of fresh water (FAO 2016). 
Industry claims the next big chunk of the world's fresh water, accounting for over twenty percent. The unprecedented growth of industry for the purpose of creating higher and higher Gross Domestic Product has become the most significant drain on fresh water resources. Unprecedented population growth and a growing desire for more consumption during the last six decades have fueled the greater extraction of natural resources, large-scale production and increasing levels of consumption. Technological innovations and increasing mechanization have facilitated the process of producing more and more. World GDP has grown in 54 of the 55 years since 1961. Year 2009 was the only exception. Approximately 16 to 20 percent of this growth comes from the manufacturing sector alone (World Economics, Global Growth Tracker 2016). Massive industrialization is throwing off the balance between humans and nature on many continents, especially in rural Latin America and Asia where export-oriented agri-business is claiming more and more of the fresh water once used by small farmers for increasing food self-sufficiency. Despite technological innovation, most of the world's growing industries are water intensive. For example, it takes about 400,000 liters of water to make one car. Manufacturers of computers and other electronic goods use massive quantities of de-ionized fresh water to produce their goods. Chemical and pharmaceutical industries and manufacturers of beverages consume very large quantities of fresh water. Originally thought to be a 'clean' industry, high-tech industry has left a staggering pollution legacy in its short history (Barlow - Clarke 2002: 5-9). Nuclear power plants also need a massive supply of fresh water. Similarly, the extraction of minerals is also highly water-intensive. With a growing appetite for minerals, fresh water supplies are dwindling in mineral extraction belts. In view of the facts given above, global water consumption has grown at more than double the rate of population growth in the last century. Global water use soared from estimated 770 billion cubic meters in 1900 to 3853 billion cubic meters in 2010 and is projected to climb to 5000 billion cubic meters by 2025 (FAO 2016).

Growing water consumption has threatened planet's finite fresh water resources. Major river systems are under stress. The Nile in Egypt, the Ganges in India, the Yellow River in China and the Colorado River in the United States are reported to be the worst victims. They are so overexploited that very little or no fresh water reaches its final destination. Other river systems are also under stress. Studies have revealed that all major lakes are shrinking and water levels are declining substantially. In addition, numerous smaller lakes have dried up completely as if they never existed. Groundwater has also substantially declined across the world. The problem with groundwater is that its depletion cannot be seen, unlike that of rivers and lakes. Massive groundwater extraction not only causes the depletion of finite aquifer reserves, but it also dramatically reduces the 
water table in the surrounding areas. If extraction continues to exceed recharge over time, water also becomes contaminated with dissolved minerals. Mining, production and oil extraction are major culprits in this process. Groundwater has also become more contaminated due to dissolved minerals. Similar conditions are being created in many parts of the world due to the over-exploitation of fresh water resources. If we continue on this path, sooner rather than later we are doomed to face serious water shortages that severely impact human life across the globe (Barlow - Clarke 2002; Pennington - Cech 2010).

Growing water consumption and a scarcity of water are not the only problems. Increases in the pollution of water bodies poses an even more serious ecological threat. Water is a good solvent, thus most pollutants dissolve in it easily and contaminate it. The most basic effects of water pollution are suffered directly by the organisms and vegetation that survive in water, including amphibians. It is well known that in terms of human life, numerous people die each day from consuming polluted and infected water. The growth of the bottled water industry and water treatment technology during the last 3-4 decades is a clear indication of such growing water contamination across the globe. When toxic substances dissolve in bodies of water, such as streams, rivers and lakes, water becomes polluted. Pollutants tend to be suspended in the water or deposited on the bed. They degrade the quality of water over time. This usually means that one or more substances have built up in water to such an extent that they become harmful to the user. When the natural composition of water is affected owing to the encroachment of any unwanted compound into it, then it is no longer pure water and is called polluted (Pollution Pollution 2017).

All human beings pollute water in one way or the other, whether knowingly or unknowingly. There are multiple human-induced causes of water pollution across the globe although their intensity differs from place to place. The single biggest threat of water pollution comes from the enormous amount of sewage that is generated in ever-growing cities across the world. Such civic effluent is called sewage, and contains both organic and inorganic waste. Organic waste includes organic compounds, waste food, fuels, human and animal waste, waste from trees, plants, etc. while inorganic waste includes a variety of chemicals, pesticides, toiletries and cosmetics, fertilizers, plastics, and so on. Wastewater, on the other hand, is defined as a combination of one or more of the following components: domestic effluent, industrial effluent, water from commercial establishments and institutions, storm water and other urban runoff, agricultural, horticultural and aquaculture effluent, either dissolved or as suspended matter. More than two-thirds of the domestic sewage and wastewater in sixty percent of the countries in the world is directly dumped into various water bodies - rivers, streams, lakes and seas. The proportion of domestic 
sewage and waste water discharged into water bodies in developing counties is much higher, in many cases up to $100 \%$. One global estimate by UNDP and UN-Habitat is that $90 \%$ of all wastewater that is generated is released into the environment untreated (Corcoran et al. 2010).

Until now we have tried to briefly describe the most important waterrelated issues and severe global problems, from water scarcity to over-use and water contamination and pollution, all explainable by the theory of $\mathrm{CPR} /$ collective action, as mentioned before. The picture is not so bright, but we believe that there is way out of this international social trap. Thus, in the following sections we enter into the terrain of potential solutions that are directly or indirectly related to sustainability, sustainable water use, and governance and policies, often realized with the help of international agreements and institutions.

\section{SUSTAINABLE WATER USE, MANAGEMENT AND GOVERNANCE}

First, we clarify the notion of sustainable development (SD) in general and then "translate" it to the sustainable use of water. Sustainable development is a universally accepted notion and concept used and referred to both in political rhetoric and by various international organizations and institutions - e.g. the UN, and EU - and in scientific life. Despite the fact that the term has already been used for decades and can be defined in several different ways - essentially all meaning the same thing - debate is still ongoing even in professional circles about what it really means, and how it can be translated into a form that makes action feasible.

As for the evolution and institutionalization of the concept, one of the first - and probably most influential - scientific warnings, "The Limits to Growth" (Meadows et al. 1972), was published in the year that the first UN world conference in Stockholm was devoted to the critical interrelation of human development and its environmental impact ${ }^{4}$. The latter initiated action programs which were concerned with the environmental protection of settlements, including the management of natural resources, the contamination of the sea, and the relationship between development and environment. Nonetheless, only one decade later - with the exacerbation of global environmental problems and their socio-economic effects - the problem had become more broadly interpreted and incorporated into the concept of sustainable development and operationalized

4 Called "The UN conference on the Human Environment". 
in the form of new international agreements and institutions. First, the World Commission on Environment and Development (WCED) was founded in 1983 upon the request of the UN's general secretary, led by Gro Harlem Brundtland (Norwegian Prime Minister), which is why it was also called the "Brundtland Commission". Then - from 1983-1987 - these actors prepared a far-reaching and comprehensive report urging significant changes, which later became the well-known "Our Common Future" or "Brundtland Report". The document stated that: "sustainable development is development that meets the needs of the present without compromising the ability of future generations to meet their own needs" (WCED 1987:43).

So it was in 1987 that the concept of harmonious or sustainable development was first expressed in an international document. Two important issues must be scrutinized, however. According to the "Report", the principle of sustainable development is a mutual and also international agreement, but due to its theoretical format, implementation will be different in each country, region or small local community. So the advantage of the principle is also its disadvantage, and sustainable development may be interpreted in a lot of ways which may later bring about conflict. The other issue is that the perspective of both the economy and society must change. And this is perhaps the most important element of the theory of sustainable development, since the prevailing development trends and politics should be changed radically. As for natural resource use, the "Report" raises both inter-generational and intra-generational equity concerns. On the one hand, inter-generational equity means incorporating the needs of future generations into the design and implementation of current policies. Intragenerational equity, on the other hand, means meeting the needs of present generations trapped in poverty because of unsustainable development (Baker et al. 1997).

Overall, the theory of SD leads a double life: it has a very positive mission, which may not be defined well and which is even more difficult to operationalize. We believe that it may best be approached as a methodology, or rather a comprehensive, strategic and long-term way of thinking involving the communal making of social decisions which take into account the consequences of such decisions from an economic, social and environmental point of view (Orbán 2005). An indispensable part of this collective thinking and decision making is that increasing numbers of people should be involved in it, each representing their own interests, from local to global; each trying to find common solutions to the - above-mentioned-CPR problems. If we accept this approach, then we can also agree that there exist a growing number of good international precedents of this type of thinking - just think of the UN MDGs or SDGs - which give grounds for optimism. 
On the other hand, we often encounter the other manifestation of SD in international practice too. This is sustainability as an "empty buzzword": effective and popular, but without meaning - according to the above-mentioned interpretation - which some find it absolutely necessary to include in any document that involves the formulation of either a decision or a plan connected to economic development and business. Besides this, there have been a great number of conferences and events whose main topic has been sustainable development, or an economic or political issue closely related to this, in which famous experts, politicians and non-governmental organizations have participated. However, regarding the outcomes and after-life of the former, they have been of questionable value and most of the time have represented "business as usual", so we have again witnessed the usual, short-term implementation of economic-business interests (Orbán 2005).

In summarizing, as well as in offering a kind of solution to the above-mentioned problems, we can state the following: The principle of sustainable development is present in many forms internationally, but its successful and practical implementation (not just in terms of formalities) requires a strategic, holistic, multidimensional perspective, and local community and participatory decision making. There seems to be agreement among experts (see for example, Boyd 2001; Roberts - Colwell 2001; Southey 2001; Rydin 1997, among others) that the key to successful implementation is the participation of different economic, political and social players of regions, small territories and local communities within nations; i.e. local governments, social and economic organizations, and civil initiatives, or in other words, social partners - often called "stakeholders" in various project documents - in drawing up concrete programs. Sustainable development strategies differ in quality, ranging from zero impact through poor to ideal, thus the applicable economic and environmental policies and development strategies can vary to a great extent (Baker et al. 1997). Stronger or ideal - strategies require a holistic approach, inter-sectoral economic policy, involvement of the scientific and cultural sphere, the widest possible strata social, and bottom-up initiatives. From this strong sustainability perspective, it is very important that local governments, regional development organizations, trade unions, civil initiatives, educational and scientific institutions and related local communities (i.e. all those concerned) play a role in the working out and implementation of sustainable development strategy (Baker et al. 1997; Orbán 2005).

To translate this general overview into a sustainable approach to using and managing water, we should mention some well-known theoreticians again. For instance, Elinor Ostrom, in her book "Governing the Commons" (1990), offered alternative solutions to the traditionally supported state and market ones in terms 
of common-pool resource (CPR) problems by examining how communities may try to "govern their commons" through voluntary organizations. The cases in her research mainly involve agriculture, such as the communal tenure of meadows and forests, irrigation communities and fisheries. We consider her approach essential to our argumentation, as we claim that internally motivated - i.e. community-derived - solutions to public goods/CPR problems can help individuals who live in communities to develop such rules and mechanisms that later become institutionalized (external) solutions that are "ready tools" for use in future conflict resolution, even in the worst case of transboundary international water conflict.

Sustainable water use and/or management have been among the issues most discussed internationally in recent years. This new and highly desirable approach is an alternative to traditional water use and management, involving integrated water management and total water cycle management - which was earlier widespread -, often in an urban context (where the most severe examples of water stress and contamination can be found) in the form of sustainable urban water management (SUWM). SUWM is characterized by the earlier-mentioned, critical new dimensions of sustainability such as taking a long-term perspective, employing an integrated approach and infrastructure, and employing biophysical systems which provide water both for ecological and human use, and which consider the economic, social and environmental as well as the political context (Meene et al. 2011). There are many new initiatives, examples of best practice and technical innovation worldwide, ranging from the US through Europe to Australia; however, reading the latest Budapest Water Summit policy recommendations, for instance (see the next sub-chapter), we cannot say that the above-mentioned problems have been solved, or that internationally binding rules and policies have been widely accepted.

Important drivers and obstacles can be found among the "soft factors" in the socio-cultural and political terrain of water use and management. As Meene and colleagues (2011) have reported, despite technical advancements in sustainable urban water management, the shift from traditional to preferred alternative and sustainable uses is slow, partly due to socio-institutional barriers and a lack of understanding of the importance of sustainable water governance. The authors state that there is limited research, understanding and contemporary commentary about sustainable water governance issues. Moreover, current scholars rather emphasize the importance of network governance, while water management practitioners and experts support a hybrid approach, relying on traditional, hierarchical and centralized-, as well as market and network methods and solutions (Meene et al. 2011). 
While sustainable water use and governance are conceptualized as being strongly needed, we see that realization is another question: locally suitable approaches and innovative models must be found by local communities themselves. This is not an easy task: it involves a complicated, demanding, mutually influential learning process. There have been many "best practice" initiatives for sustainable water use and governance that involved the earlier mentioned holistic vision, participatory decision making, and transdisciplinary learning worldwide. Some researchers in Switzerland (Schneider - Rist 2014), for instance, combined normative, explorative and participatory elements in their "MontanAqua" sustainable water management and governance envisioning project, which allowed them to adequately consider both the understanding and systems and transformation knowledge of interested stakeholders and scientists. They have shown that there is significant potential for co-producing new knowledge and establishing a deliberative dialogue between all stakeholders and actors who are involved. Nevertheless, they also warn that such kinds of participatory, communicative approaches and forms of interaction cannot be realized without the existence of mutual trust and the equal treatment of both theoretical/scientific and practical stakeholder knowledge (Schneider Rist 2014). Knowledge sharing, exchanges of information and diminishing the so-called knowledge gap or science-policy gap between scientists, stakeholders and policymakers is not easy, however, as other researchers have found when discussing the role of water information in efficient decision-making and water management (Timmerman - Langaas 2005). These authors argue that although scientifically and technologically better information can be produced, the use and production of such information will be still limited and hindered as long as the different mindsets, interpretations and evaluations of information by various stakeholders is not taken into account, and while better communication and cooperation between the different levels and scales of governance are not in evidence. Moreover, transboundary water management is further hindered by socio-cultural factors such as different historical and cultural backgrounds and institutional and legal frameworks. To improve this situation they also emphasize the earlier mentioned participatory processes whereby interactive dialogue and decision making must be facilitated to promote social learning (Timmerman Langaas 2005).

Thus we arrive again at our important argument that socio-cultural "soft" factors do matter, and are very important both in sustainable water management and governance: these factors include decreasing the knowledge gap and balancing information asymmetry through participatory communication and learning processes and creating forums and institutions both for understanding the interests of various stakeholders and negotiating conflicts and problems, even if they are transboundary in nature. 


\section{CONCLUSION}

We started our discussion with the African quotation that "water is life" and have tried to convince the reader about the modern truth of this old ancient saying by describing the threatening and alarming picture of water overuse and pollution, and the still on-going unsustainable use and management of water. The World Water Council in its World Water Vision Report concluded the following to the Second World Water Forum in March 2000 at The Hague:

"Water is life, in all forms and shapes. This basic yet profound truth eluded many of us in the second half of the 20th century. Water professionals and scientists around the world were ringing the alarm bells of an impending water crisis. Yet attempts to address some of the issues or to offer partial solutions met with limited success. ... We start the new century with a water crisis on all accounts. A concerted effort and extraordinary measures are needed to face the challenges head on." (World Water Vision Report 2000:1)

We can say that much effort has been made, many forums, conferences and negotiations have been held and international agreements have even been created, although not much has changed. As János Áder, President of Hungary, said at the Budapest Water Summit 2016, "water is the most important question of the twenty-first century, our indispensable and irreplaceable resource". The "messages" of the summit are in harmony with our argument that water is a critical global asset and it is in crisis. Participants agreed that if everything is left unchanged in the next 15-20 years, there will be a serious water crisis. The Budapest Water Summit 2016 international conference both summarized the achievements of water-related development policy and contributed to the selection of tasks for the next fifteen years. Water-related investments need to be supported using new, innovative financial solutions, and development banks should support the proliferation of new water industry technologies. Experimental programs need to be initiated across the world to prevent a looming water crisis that could threaten billions of people. Participants discussed how to promote integrated approaches to water management and identified the most important areas for action. To create concrete, pragmatic policy solutions to challenges related to water, the Budapest Water Summit 2016 Policy Recommendations were elaborated, covering all the thematic areas which are directly or indirectly

\footnotetext{
5 Source: Documents from the "Budapest Water Summit, 2016," accessed at: https://www. budapestwatersummit.hu/budapest-water-summit/news/, 2 August, 2017
} 
related to water and can be carried out along the lines of the 2015 SDGs, addressing water-related issues such as universal and equitable access to safe drinking water and sanitation, pollution, water quality, water scarcity, water use efficiency, equitable allocation, maintenance of the integrity of waterdependent ecosystems, resilience and social equity. As the summit concluded, these water issues are inter-related, interdependent, and must be addressed in a systemic and globally-consistent manner, while also including both public and private stakeholders, as well as businesses and financial resources, to promote sustainable development.

Based on our earlier discussion and arguments, we would finally like to emphasize the indispensable role of "soft" socio-cultural factors in sustainable water use and management, remembering those great, ancient civilizations in which the contemporary and highest level of technical knowledge was not enough to enable them to survive. We believe that negotiation and participationbased forums such as the Budapest Water Summit help to decrease both the knowledge gap and information asymmetry, to smooth communication channels, and help solve international social dilemmas concerning the water crisis by preparing the ground for effective and sustainable water governance and policies, both at a local and global level.

\section{REFERENCES}

Baker, Susan - Kousis, Maria - Richardson, Dick - Young, Stephen (1997), The Theory and Practice of Sustainable Development in EU Perspective, in S. Baker et al. (eds.), The Politics of Sustainable Development. Theory, Policy and Practice within the European Union. London-New York, Routledge

Barlow, Maude - Clarke, Tony (2002), Blue Gold. The Battle Against Corporate Theft of the World's Water. London, UK, Earthscan Publications Ltd.

Boyd, Susan, F. (2001), Sustainable Communities and the Future of Community Movements. National Civic Review, Vol. 90, Issue 4, pp. 385-390, DOI: 10.1002/ncr.90409

Chellaney, Brahma (2011), Water; Asia's New Battle Ground, Washington D.C. USA, Georgetown University Press

Chellaney, Brahma (2013), Water, Peace and War: Confronting the Global Water Crisis. Plymouth, UK. Rowman \& Littlefield Publishers Inc.

Corcoran, Emily - Nellemann, Christian - Baker, Elaine - Bos, Robert -David, Osborn-Savelli, Heidi eds., (2010), Sick water?: the central role of wastewater 
management in sustainable development : a rapid response assessment. United Nations Environment Pro-gramme, UN-HABITAT, GRID-Arendal. (PDF online). Available at: http://staging.unep.org/pdf/SickWater_screen.pdf, Accessed 1 March, 2017.

Diamond, Jared, M. (1994), Ecological Collapses of Ancient Civilizations: The Golden Age that Never Was. Bulletin of the American Academy of Arts and Sciences, Vol. 47, No 5. pp. 37-59.

Escobar, Isabel - Schafer, Andrea (2010), Sustainable Water for the Future. Amsterdam, The Netherlands. Elsevier B.V.

Food and Agriculture Organization (FAO) (2016), Aquastat. Available at: http://www.fao.org/nr/water/aquastat/didyouknow/index3.stm, Accessed 1 March, 2017.

Hankiss, Elemér (1979), Társadalmi csapdák. (Social Traps). Budapest, Magvető Kiadó

Hardin, Garrett (1968), Tragedy of the Commons. Science, New Series, Vol. 162, No 3859. pp. 1243-1248.

Kameri-Mbote, Patricia (2007), Water, Conflict, and Cooperation: Lessons from the Nile River Basin. Navigating Peace, No.4, January 2007, Woodrow Wilson International Center for Scholars, (PDF) Available at: http://www. wilsoncenter.org/water, Accessed 20 January, 2010.

Kuil, Linda - Carr, Gemma - Viglione, Alberto - Prskawetz, Alexia - Blöschl, Günter (2016), Conceptualizing socio-hydrological drought processes: The case of the Maya collapse. Water Resources Research, 2016; DOI: 10.1002/2015WR018298

Lowi, R.Miriam (2008), Scarce Water, Abundant Oil. Resources and Conflict in the Middle East and North Africa, presented at the annual meeting of the International Studies Association, San Francisco, March 26-29, 2008. (PDF) Available at: http://www.allacademic.com//meta/p_mla_apa research_citation/2/5/1/3/9/pages251392/p251392-1.php, Accessed 20 January, 2010.

Meadows, Dennis L. - Meadows, Donella H. - Randers, Jorgen - Behrens, William W. (1972), The Limits to Growth. New York, Universe Books

Meene, van de Susan J. - Brown, Rebekka R. - Farrelly, Megan A. (2011), Towards understanding governance for sustainable urban water management, Global Environmental Change Vol. 21, pp. 1117-1127.

National Research Council of National Academies, (1999). Our Common Journey - A Transition toward Sustainability. National Academy Press, Washington D.C.

Olson, Mancur (1971), The Logic of Collective Action. Cambridge, Mass.: Harvard University Press 
Orbán, Annamária (2005), Institutionalization of Sustainable Development. Theory and practice. Critical Approach. Society and Economy, Vol. 27, No 2, pp. 263-286.

Ostrom, Elinor (1990), Governing the Commons. The Evolution of Institutions for Collective Action. Cambridge: Cambridge University Press

Pennington, Karrie L. - Cech, Thomas V. (2010), Introduction to Water Resources and Environmental Issues. Cambridge, Cambridge University Press

Pollution Pollution, (2017), What is Water Pollution? [online] Available at: http://www.pollutionpollution.com/2012/08/what-is-water-pollution.html, Accessed 12 January 2017.

Priscoli, Jerome - Wolf, Aaron (2009), Managing and Transforming Water Conflicts. Cambridge, New York, USA, Cambridge University Press

Roberts, Peter - Colwell, Adrien (2001), Moving the Environment to Centre Stage: a New Approach to Planning and Development at European and Regional Levels, in Local Environment, Vol.6, No 4, pp 421-437., http://dx.doi. org/10.1080/13549830120091716

Rydin, Yvonne (1997), Policy networks, local discourses and implementation of sustainable development, in Baker, Susan et al. (eds.) The Politics of Sustainable Development. Theory, Policy and Practice within the European Union, London, Routledge

Schneider, Flurina - Rist, Stephan (2014), Envisioning sustainable water futures in transdisciplinary learning process: combining normative, explorative and participatory scenario approaches, Sustainability Science, Vol. 9, No 4, pp. 463-481. Shiva, Vandana (2000), Water Wars - Privatization, Pollution and Profit, Cambridge, MA South End Press

Southey, Sean (2001), Accelerating Sustainability: from Agenda to Action, in: Local Environment, Vol. 6, No 4, pp. 483-489, http://dx.doi. org/10.1080/13549830120091752

Timmerman, Jos G. - Langaas, Sindre (2005), Water information: what is it good for? The use of information in transboundary water management. Regional Environmental Change, Vol.5, No 4, pp. 177-187.

WCED, World Commission on Environment and Development (1987), Our Common Future: Report of the World Commission on Environment and Development, Oxford, Oxford University Press

World Water Vision, World Water Council, (PDF) Available at http://www. worldwatercouncil.org/fileadmin/wwc/Library/WWVision/Chapter2.pdf, Accessed 28 February, 2017.

World Economics, Global Growth Tracker, (2016), Available at: http://www. worldeconomics.com/papers/Global\%20Growth\%20Monitor 7c66ffca-ff864e4c-979d-7c5d7a22ef21.paper, Accessed 1 March, 2017. 
UN World Urbanization Prospects, (2014), United Nations, Department of Economic and Social Affairs. [pdf]. Available at: https://esa.un.org/unpd/ wup/publications/files/wup2014-highlights, Accessed 1 March, 2017.

UN Water. Wastewater Management. A UN Water Analytical Brief. [pdf]. Available at: http://www.unwater.org/fileadmin/user_upload/unwater_new/ docs/UN-Water_Analytical_Brief_Wastewater_Management.pdf, Accessed 8 March, 2017.

World Water Council, (2000), World Water Vision. London, Earthscan Publications Ltd. 